\title{
Regulation of Illegal Fintech Lending in Indonesia
}

\author{
Abdul Rasyid \\ Business Law Program, Law Department, Faculty of Humanities, Bina Nusantara University, Jakarta, Indonesia \\ 11480 \\ Corresponding author email: arasyid@binus.edu
}

\begin{abstract}
Presently, fintech lending in Indonesia is increasing significantly. Fintech lending is regulated with the Financial Services Authority Regulation Number 77 of 2016 concerning Information Technology-Based Money Lending and Borrowing Services. Until November 2020, there was 154 lending fintech registered and licensed in the Financial Services Authority. Besides this registered and licensed fintech lending, there are also many illegal fintech lending operating. Almost 2,591 illegal fintech lending business activities have been blocked with the Financial Services Authority. Unfortunately, this illegal fintech lendings are still emerging. Of course, this condition is not suitable for the development of lending fintech activities in Indonesia. Therefore, this paper tries to analyse why illegal fintech lending continues to emerge even though the Financial Services Activities has made various efforts to prevent it. The study of this research uses normative juridical. This paper concludes that the current regulations governing fintech do not strictly regulate illegal fintech lending. There need to be strict and heavy sanctions given to the perpetrators who carry out illegal fintech lending activities so that no one else dares to carry out such activities again.
\end{abstract}

Keywords: Regulation, illegal fintech, lending

\section{INTRODUCTION}

Currently, the financial services industry is experiencing significant innovation in line with digital technology's rapid development. Financial service innovations that have been influenced by current technological developments are known as financial technology (fintech). Fintech first appeared and developed in countries with world economy centres, such as the United States, Britain, and China [1]. Then it entered Indonesia and increased in line with the increasing needs of the community.

In simple terms, fintech can be understood as a fusion between technology and financial services. According to the Financial Stability Board, fintech is as technologically enabled innovation in financial services that could result in new business models, applications, processes, or products with an associated material effect on financial markets and institutions and the provision of financial services. Fintech innovations are affecting many different areas of financial services [2]. Meanwhile, according to the National Digital Research Centre (NDRC), fintech is a term used to describe innovation in financial services. The word fintech comes from the word financial and technology, which refers to financial innovation with a touch of modern technology [3]. Cell phones as mobile banking and investment services can be used as an example of combining technology with the financial system to provide financial services that are more accessible to the broader community [4].

Fintech offers various types of financial services, such as peer to peer (P2P) lending, crowdfunding, and payment gateways. Among the types of financial services provided by fintech, fintech $\mathrm{P} 2 \mathrm{P}$ lending is the most widely used by the public. By the end of the second quarter of 2020, fintech lending dominated around $44 \%$ of the fintech business, followed by fintech in the Digital Financial Innovation category at $24 \%$, digital payments around $17 \%$, and equity crowdfunding much as $1 \%$ [5].

Fintech lending is one of the innovations in the financial sector using technology that allows lenders and loan recipients to carry out lending and borrowing transactions without meeting in person. The lending and borrowing transaction mechanism is carried out through a Fintech Lending Operator system, either through the application or on the website page. Fintech lending is in great demand by the public because it provides fast funding, mostly without collateral. The terms and processes are more straightforward because they can be done remotely using smartphones [6].

According to data from the Financial Services Authority (FSA), as of November 2020, there were 154 fintech lending companies registered and licensed with the FSA [7]. As of October 2020, loan disbursements provided by fintech lenders had reached IDR 56.16 trillion [8]. This figure is still 
relatively small because, based on the FSA's research in 2016, Indonesia has a funding gap of IDR 989 trillion per year. The funding required by the community annually is IDR 1,649 trillion, but all of them cannot be met by financial institutions, which only have a total flow of funds of IDR 660 trillion. Therefore, the fintech industry in Indonesia still has enormous potential to be further developed in the future, considering that there is still a lot of funding needed by the public that has not been fulfilled [9].

Concerning regulations, fintech lending is regulated by the FSA Regulation No. 77/POJK.01/2016 concerning Information Technology-Based Lending and Borrowing Services (hereinafter abbreviated as POJK NO.77). With the development of fintech, the Financial Services Authority again issued the Financial Services Authority Regulation Number 13/POJK.02/2018 concerning Digital Financial Innovation in the Financial Services Sector (hereinafter abbreviated as POJK No.13). This regulation strengthens fintech supervision and regulation in Indonesia. The difference between the two regulations above is that POJK NO.77 is a more specific legal framework regulating fintech lending types. In contrast, POJK No.13 regulates financial technology start-ups with new business innovations that have not been regulated by the previous regulation.

Furthermore, the above regulation requires that all fintech lenders operating in Indonesia be registered and licensed by the Financial Services Authority. Unfortunately, many illegal fintech lendings have emerged and are easily accessible to the public until now. The existence of illegal fintech lending has caused many losses to society. Therefore, this paper analyses why illegal fintech lending continues to emerge, what steps should be taken to overcome illegal fintech lending, and how illegal fintech lending in Indonesia is regulated.

\section{METHODOLOGY}

Research of this paper is normative legal research. The research is utilizing secondary data collected through a literature study with regulations as the primary legal sources.

\section{RESULT AND DISCUSSION}

\subsection{Illegal Fintech Lending}

Fintech lending operating in Indonesia must be registered and licensed by FSA. As mentioned above, currently, 154 fintech lendings have been registered and licensed with the FSA. However, in addition to these registered and licensed fintech lenders, there are also fintech lendings that operate illegally, are not registered, and have obtained permission from the FSA. This fintech lending works illegally, is easily accessible to the public, and continues to emerge, especially during the current Covid-19 pandemic where the level of public funding needs is increasing. Despite have been blocked by the Investment Alert Task Force [10], illegal fintech lendings are still emerging. Many people borrow money from them, even though they are very close to high-interest risks and legal problems. During 2018-2020, the Investment Alert Task Force has stopped 2,591fintech lending activities without FSA permission [11].

According to Tongam L. Tobing, Head of the Investment Alert Task Force, there are two reasons why illegal fintech lending companies are still rife in Indonesia, 1.With advances in technology and information systems today, it is effortless to create websites or applications so that anyone can easily offer online loans through this illegal fintech lending. 2. The level of public understanding is still low on illegal fintech lending. Many people always respond to the online loan which is offered by fintech lending illegal, especially people who need money. To overcome this problem, the Investment Alert Task Force has taken various preventive measures by continuously providing education to the public. They are strongly suggested not to make online loans to illegal fintech lending and only make an online loan to official fintech lending registered and licensed by the FSA. Also, the Investment Alert Task Force have made efforts to cease activities, announced to the public, asked the Ministry of Communication and Information Technology to block all web and illegal fintech lending applications in all technology and information systems, and asked the police take legal action if it is suspected that a criminal act has been committed by the illegal fintech lending activity [12].

Below are some of the fundamental differences between legal and illegal fintech lending that the public must know [13]: 
TABLE 1. Differentiation between illegal fintech lending and licensed / registered fintech lending

\begin{tabular}{|c|c|c|c|}
\hline No & & Illegal fintech lending & $\begin{array}{c}\text { Licensed / registered fintech } \\
\text { lending }\end{array}$ \\
\hline 1 & Regulator & $\begin{array}{l}\text { There is no special regulator in } \\
\text { charge of overseeing the } \\
\text { activities of illegal fintech } \\
\text { lending providers. }\end{array}$ & $\begin{array}{l}\text { Under the supervision of the } \\
\text { FSA. Very concerned about the } \\
\text { aspects of consumer protection. }\end{array}$ \\
\hline 2 & Borrowing terms & $\begin{array}{l}\text { It tends to be very easy without } \\
\text { asking for loan needs. }\end{array}$ & $\begin{array}{l}\text { Need to know the purpose of the } \\
\text { loan and require documents for } \\
\text { credit scoring. }\end{array}$ \\
\hline 3 & Interest and fines & $\begin{array}{l}\text { Imposes enormous fees and } \\
\text { fines and is not transparent. }\end{array}$ & $\begin{array}{l}\text { Need to know the purpose of the } \\
\text { loan and require records for } \\
\text { credit scoring. Imposes massive } \\
\text { fees and fines and is not } \\
\text { transparent. They are required to } \\
\text { provide disclosure of information } \\
\text { regarding interest and the } \\
\text { maximum penalty set on Users. } \\
\text { The Indonesian Joint Funding } \\
\text { Fintech Association (AFPI) } \\
\text { regulates a full loan fee of } 0.8 \% \\
\text { per day, and the total cost, } \\
\text { including fines, is } 100 \% \text { of the } \\
\text { principal amount of the loan. }\end{array}$ \\
\hline 4 & Billing method & $\begin{array}{l}\text { Billing method. Billing } \\
\text { procedures are unethical and } \\
\text { not following the rules. } \\
\text { Frequent collection in rude } \\
\text { ways tends to be threatening, } \\
\text { inhuman, and contrary to the } \\
\text { law. }\end{array}$ & $\begin{array}{l}\text { Collectors are required to follow } \\
\text { the collection of personnel } \\
\text { certification conducted by AFPI. } \\
\text { Billing is submitted to the billing } \\
\text { service registered with AFPI so } \\
\text { that it can be monitored. The } \\
\text { billing process can be tracked. If } \\
\text { violations are found, FSA/AFPI } \\
\text { can impose sanctions. }\end{array}$ \\
\hline 5 & $\begin{array}{l}\text { Access personal } \\
\text { data }\end{array}$ & $\begin{array}{l}\text { questing access to all personal } \\
\text { data in the user's cell phone } \\
\text { (HP). Information is misused } \\
\text { when billing. If the photos are } \\
\text { accessed, they can view and } \\
\text { copy all the pictures on the } \\
\text { user's cell phone. }\end{array}$ & $\begin{array}{l}\text { Only allowed to access the } \\
\text { camera, microphone, and } \\
\text { location on the user's cell phone. } \\
\text { Not allowed to access data other } \\
\text { than above. }\end{array}$ \\
\hline 6 & $\begin{array}{l}\text { Regulatory } \\
\text { compliance }\end{array}$ & $\begin{array}{l}\text { Not subject to FSA Regulations } \\
\text { and other regulations }\end{array}$ & $\begin{array}{l}\text { Must comply with the } \\
\text { regulations, both } \\
\text { Regulations, and applicable laws } \\
\text { and regulations. }\end{array}$ \\
\hline 7 & Status & $\begin{array}{l}\text { Carry out activities without } \\
\text { obtaining permission from the } \\
\text { competent authorities }\end{array}$ & $\begin{array}{l}\text { Legal status following FSA } \\
\text { Regulation No. } 77 \text { / POJK.01 / } \\
2016 .\end{array}$ \\
\hline
\end{tabular}

Based on the explanation above, the public must be careful and not try to make online loans to illegal fintech lending. Illegal fintech lending does make it easier for people to provide loans. It is enough just by providing a photocopy of the resident's identity card and self-portrait. The borrower will be given a 
loan, but with one condition, to access all data and contact numbers on the prospective borrower's cell phone. This can certainly be detrimental to borrowers because borrower data can be stolen and traded and used to intimidate or terrorize borrowers if they cannot pay their loans.

Also, illegal fintech lending commits fraud by faking logos and names similar to fintech lending operators registered and licensed with the FSA. Therefore, before making an online loan, the public must first confirm whether the fintech lending company has been registered and obtained permission from the FSA or not. The public can also check registered and licensed fintech lending information regularly on the FSA website. By doing this, the public can avoid various unwanted risks due to making online loans at illegal fintech lending.

\subsection{Regulation of Fintech Lending}

The development of the digital economy also affects people's behaviour in lending and borrowing activities. The community continues to develop service provision innovations in lending and borrowing activities, one of which is marked by the provision of Information Technology-Based Lending and Borrowing Services, also known as fintech lending. Fintech lending helps increase public access to online financial service products, with various parties without knowing each other. With this information technology-based lending and borrowing service, it is hoped that it can meet cash needs quickly, easily, and efficiently, increase competitiveness, and be one of the solutions to help micro, small and medium scale businesses in obtaining access to funding [14].

Considering that the information technologybased lending and borrowing service business activities carried out by fintech lending providers have developed in the community, it is necessary to regulate and monitor it to provide legal certainty and maintain order. Therefore, in 2016, the FSA, the institution authorized to supervise and control these activities, issued FSA Regulation Number 77/POJK.01/2016 concerning Information Technology-Based Borrowing and Lending Services.

According to Article 1 (6) POJK No. 77, a fintech lending provider is a financial service institution with an Indonesian legal entity. These legal entities can be in the form of Limited Liability Companies and Cooperatives. Besides, Article 7 POJK No. 77 stipulates strictly that operators wishing to carry out fintech lending activities must register and obtain permission from the FSA. Providers who have carried out fintech lending activities before enacting this FSA regulation must submit an application for registration to the FSA no later than six months after this POJK No. 77 comes into effect (Section 8 (2). And the application for permission is a maximum of one year after the providers are registered with the FSA.

The POJK No. 77 also regulates registered and licensed fintech lending obligations, providing periodic reports to the FSA every three months. Fintech is also required to have qualified human resources who have expertise and background in information technology. Meanwhile, for the protection of lenders and recipients of loans, administrators, based on Article 29, must apply the principles of transparency, fair treatment, reliability, confidentiality, data security, fast and straightforward dispute resolution, and affordable costs for users.

Based on the explanation above, it can be understood that fintech lending providers must be registered and obtain permission from the FSA. If a fintech lending provider carries out activities without registering and obtaining permission from the FSA, it is considered to be carrying out illegal activities. But unfortunately, POJK No. 77 does not regulate the supervision and sanctions given to providers who illegally carry out fintech lending activities. This is also not regulated in the FSA Regulation No.13/POJK.02/2018 concerning Digital Financial Innovation in the Service Sector Finance. No precise regulation in POJK No. 77 and POJK No. 13 regarding the strict supervision and sanctions that will be given to illegal fintech lending providers; according to the author, is one of the causes of illegal fintech lending still to emerge and carry out its activities.

\section{CONCLUSION}

Fintech lending is currently growing rapidly and has the potential to develop even more in the future. This is because the funding needs needed by the community are still not fulfilled by financial institutions. In carrying out their activities, fintech lending providers must register and obtain permission from the Financial Services Authority. Unfortunately, many illegal fintech lendings have sprung up and operated until now, even though the Investment Alert Task Force has blocked them. What has been done by the Investment Alert Task Force in dealing with illegal fintech lending is very worthy of appreciation. Unfortunately, illegal fintech lending is still popping up and increasing, especially during the Covid-19 pandemic. 
If we look at the regulations, it is obvious that the regulations regarding illegal fintech lending are not clearly regulated in POJK No. 77 and POJK No. 13 and POJK No. 13. The absence of clear regulations regarding illegal fintech lending in the Financial Services Authority Regulation, according to the author, can be exploited by irresponsible parties to carry out fintech lending activities illegally. This will certainly harm society and harm the development of fintech lending in Indonesia. Therefore, to overcome this illegal fintech lending activity, it is necessary to make clear rules accompanied by strict and heaviest sanctions given to illegal fintech lending providers to cause a deterrent effect for them not to do it again.

\section{REFERENCES}

[1] A. C. Appy, S. Kasiyanto, and C. F. Napitupulu, "Teknologi Finansial di Indonesia: Tantangan Dari Sisi Pengaturan," Bul. Huk. Kebanksentralan, vol. 14, no. 2, 2017

[2] https://www.fsb.org/work-of-the-fsb/financialinnovation-and-structural-change/fint

[3] https://koinworks.com/blog/definisi-fintech/

[4] Lenny Sanicola, "what is Fintech? https://www.huffpost.com/entry/what-isfintech_b_58a20d80e4b0cd37efcfebaa

[5] https://keuangan.kontan.co.id/news/mulaiberkembang-tahun-2016-begini-kondisifintech-indonesia-hingga-kuartal-ii-2020

[6] https:/www.ojk.go.id/id/kanal/iknb/data-danstatistik/direktori/fintech/Documents/FAQ\%2 0Fintech\%20Lending.pdfCari data penelitian OJK.

[7] https://www.ojk.go.id/id/kanal/iknb/financialtechnology/Pages/Penyelenggara-FintechLending-Terdaftar-dan-Berizin-di-OJK-per-5November-2020.aspx
[8] https://www.ojk.go.id/id/kanal/iknb/data-danstatistik/fintech/Pages/Statistik-FintechLending-Periode-Oktober-2020.aspx

[9] Abdul Rasyid, 'Sekilas Perkembangan Fintech di Indonesia', https://businesslaw.binus.ac.id/2019/03/19/sekilasperkembangan-fintech-di-indonesia/

[10] Satuan Tugas Waspada Investasi merupakan wadah koordinasi antar regulator, instansi pengawas, instansi penegak hukum dan Pihak lain yang terkait dalam hal penanganan dugaan tindakan melawan hukum di bidang penghimpunan dana masyarakat dan pengelolaan investasi. Satuan Tugas Waspada Investasi ini merupakan hasil kerjasama beberapa instansi, yang meliput Otoritas Jasa Keuangan, Kementerian Perdagangan, Kementerian Komunikasi dan Informatika, Kementerian Koperasi dan Usaha Kecil dan Menengah, Badan Koordinasi Penanaman Modal, Kejaksaan, dan Kepolisian RI. https://waspadainvestasi.ojk.go.id/news/ojk-

[11] perkuat-satgas-waspada-investasi.

https://finansial.bisnis.com/read/20200713/56 3/1265429/ojk-cabut-izin-2.591-fintechilegal-sepanjang-2018-2020

[12]

https://www.youtube.com/watch?v=43VM DNbNr44

[13] https://www.ojk.go.id/id/kanal/iknb/data-dan statistik/direktori/fintech/Documents/P2PL\%2 0legal\%20vs\%20ilegal.pdf

[14] Explanation of the Financial Services Authority Regulation No. 77/POJK.01./2016 concerning Information Technology-Based Lending and Borrowing Services. 